\title{
Intensity of Sales Turnover and Promotional Expenditure and the Likelihood of New Product Success: Configurational Matrix of Fast Moving Consumer Goods (FMCG)
}

\author{
R. Agus Trihatmoko ${ }^{1}$ \\ ${ }^{1}$ Faculty of Economics and Graduate Study Program, Universitas Surakarta, Indonesia \\ Correspondence: R. Agus Trihatmoko, Faculty of Economics and Graduate Study Program, Universitas Surakarta, \\ Indonesia. E-mail: agustricentre@gmail.com
}

Received: October 28, 2019

Accepted: December 4, 2019

Online Published: December 15, 2019

doi:10.5430/rwe.v10n3p320

URL: https://doi.org/10.5430/rwe.v10n3p320

\begin{abstract}
The FMCG marketing phenomenon plays all elements of the marketing mix (4P's), so that each element is thought to have a high degree of complexity. The first objective of this research was to uncover the responses of buyers in the business market to the offering of a new product related to the marketing environment situation - P: promotion and other environments; and next, detecting product performance and its parameters as an evaluation tool for the success of new products. Qualitative research methodology was applied, and was designed using a grounded theory strategy and an interpretative approach, constructivism and pragmatism. Data was collected from the phenomenon of FMCG competition in traditional markets in Indonesia. The results of the research identified buyers' responses reveal that the marketing - promotion environment was directly taken into consideration by purchasing decisions; marketing environment - promotion is valued by the buyer in relation to the marketing environment - price, and the expected impact on the competitive environment - activity and results of promotion. The concepts from the results of this study have implications for the practice of corporate strategies regarding new product launches, marketing and financial budgeting, brand strategy, and marketing market performance. All these matters show that the depth of the purchasing behavior perspective, as well as the performance and success of a product based on promotional strategies is the originality of this paper.
\end{abstract}

Keywords: business buyer behavior, corporate strategy, fast moving consumer goods (fmcg), marketing mix, new products and competition, promotion strategy

\section{Introduction}

Promotion consists of several types of mix, namely advertising, personal selling, propaganda or mass publication, sales promotion or trade promotion (Trihatmoko, 2016; Kotler \& Armstrong, 2013; Evans \& Berman, 1992; Ziliani et al., 2019). Trihatmoko et al. (2016a) identified that the salesperson's role in the product marketing function is very complex. Therefore, this paper does not explore or promote the promotion of personal selling types. Moreover, promotion is related to supply chain management (Xiao et al., 2005; Jin et al., 2015; Tsao \& Sheen, 2012; Power et al., 2001; Jin et al., 2015; Breiter \& Huchzermeier, 2015). Self promotion is classified as above the line (ATL) and below the line (BTL) activities for advertising activities (Siddiqi et al., 2015). In addition, promotional programs in the context of sales activities consist of two types of activities, namely promotion for traders (trade promotion) and promotion for consumers of product users (consumers promotion) (Kotler \& Armstrong, 2013; Evans \& Berman, 1992). Generally, it is commonly understood that promotion has impacts on increasing sales (Chaudhuri et al., 2018; Jallow \& Dastane, 2016). However, different promotional roles are intended to create customer awareness about their products, and also try to increase customer satisfaction (Siddiqi et al., 2015). Trihatmoko's (2016) research identified that promotion programs had a direct impact on the sale of new products. The results of the study are based on the judgment of buyers (wholesaler FMCG) about promotional strategies by their suppliers, so that their conceptions are understood in the purchasing policy in the business market. The results of the Trihatmoko's (2016) study were used as preliminary data for this study, since theorizations (research propositions) are minor or detailed which are seen as providing opportunities to be re-examined. Business buyer behavior or organizational purchasing behavior describes that environmental factors constitute buyer stimulus decisions in various purchasing situations (Stern \& Reve, 1980; Achrol et al., 1983; Sashi, 2009; Peter \& Donnelly Jr., 2011; Solomon, 2013; Kotler \& Armstrong, 2013). The situation 
of purchasing new products here is mix-purchase type, since suppliers offer new products (new-task purchace) together with existing products that are already established (straight re-purchasing) (Robinson, Faris \& Wind, 1967; Jackson, Jr., Keith \& Burdick, 1984; Sashi, 2009; Peter \& Donnelly Jr., 2011; Solomon, 2013).

The first objective of this research was to uncover buyers' responses to the offer of a new product related to the marketing environment situation - P: promotion and other environments. The promotion strategy by FMCG companies is estimated to be one of the factors that determine the success of a product. However, the tight market competition is estimated to be a "challenge or opportunity" to the success of the product itself. Some of the following previous studies have sought to explore various types of promotions and advertising. Siddiqi et al. (2015) examined the BTL activities on product customer satisfaction. Gautam, A. (2013) conducted a study of the "BTL" promotion strategy for the Telecommunications industry. Buil, de Chernatony \& Martínez (2013) examined the role of advertising and sales promotion in the creation of brand equity. Asad \& Gillian (2010) explore the sales promotion programs used by wholesalers to channel products to their customer relations network. Baggen et al.'s (2010) study deepened the addition of advertising expenditures related to the success of line extensions. Verbeke, Bagozzi, and Farris (2006) explored key account programs for commitment and promotion of resource allocation, namely self space. Orth, McDaniel, Shellhammer \& Lopetcharat (2004) examine the benefits of promoting brands related to consumer lifestyles. Dawes (2004) examined the effect of successful price promotion (trade promotion) on the consumer goods category. Tang, Wang \& Huang (2014) examined the promotion strategies carried out by FMCG retailers in the modern market. Pongiannan and Chinnasamy (2014) explore consumer responses to the implementation of advertising carried out by the FMCG industry. Rampier (2012) explores the sales promotion of FMCG promotion. Chen, Monroe, and Lou (1998), Wahyuni and Ginting (2017) examined the effect of price promotion related to consumer's perception and purchase intention.

Previous studies illustrates that the intensity of the promotion is very diverse in objectivity, but it is indicated that it has not yet perceived the process and success of a new product from the results of the promotion strategy itself. On the other hand, the promotion strategy is very relevant to the phenomenon of FMCG companies that tend to aggressively create product innovation (Trihatmoko \& Mulyani, 2018), because the company applies brand strategy namely line extensions, brand extensions, multi brands, and new brands (Nijssen, 1999; Martínez \& de Chernatony, 2004; Nijssen \& Agustin, 2005; Kotler \& Armstrong, 2013; Trihatmoko, 2016; Trihatmoko et al., 2018; Trihatmoko, $\&$ Purnamasari, 2019). The second objective of this research was to detect product performance and its parameters as an evaluation tool for the success of new products in market competition. Particularly, the results of this study are expected to contribute to the development of business buyers' behavior and marketing mix - p: promotion. This conception has implications for the practice of corporate strategies regarding planning and implementing new product launches, planning and evaluating the promotion budget and performance of a product, as well as brand strategy design or planning.

\section{Methods}

The research method used here was similar to the method practiced by Trihatmoko and Mulyani (2018), or similar to Trihatmoko's research and colleagues about FMCG. The research design applied was a grounded theory approach with its interpretations of constructivist and pragmatic. In the explanation above, it has been stated that this research is a follow-up to Trihatmoko's (2016) research, so that the results of his research were used as the preliminary data of this paper. The methodological combination between research strategies and interpretations was applied to overcome the complex formulation of study problems. Qualitative experts explain various data collection and analysis techniques for simple or comprehensive research that lead to this research (Proctor, 2005; Creswell, 2009; Jonker \& Pennink, 2010; Fatchan, 2011).

In this paper, it is deemed necessary to explain methodological understanding in detail, although substantively it has been presented in the Trihatmoko's prior paper. Trihatmoko's (2016) uses a phenomenological and constructivism approach to buyer responses (wholesale in traditional markets) related to promotion policies carried out by suppliers (distribution companies and principals). The research data was obtained through interviews with wholesale owners and salespersons from FMCG distribution companies in the marketing area of Surakarta, Central Java, Indonesia. In the context of this paper, it is considered that there is no need to quote the results of interviews with the informants, but it is enough to present the results and complete the results of observations. Trihatmoko's (2016) research was processed and re-analyzed (not "recycled") using a grounded theory, constructivist and pragmatism approach to provide new perspectives on the focus of this research.

The first focus of this research was to uncover environmental factors, therefore, grounded and reconstruction analyzes were carried out on the results of previous studies. It is different from the deepening of the intensity of the 
promotion strategy from the point of view of the interests of the company (principal) need to be completed with new data, namely interviews with market informants from national and multinational companies, and completed with notes on observations. This was done as well as a confirmation to undermine the results of Trihatmoko's (2016) research. Such methodological procedures and techniques are called abstractions or construct theories from the ground up to produce new findings in research (Creswell, 2013; Fatchan, 2011).

Creswell's (2013) direction was applied in the research, an attempt to make a "bottom up" abtraction of the phenomenon of the intensity of promotional strategies in market participation as a creation to build new theories and conceptions. Conception was developed using constructivism analysis with a complementary technique (Fatchan, 2011; Creswell, 2013; Taylor et al., 2016), so that it can lead to pragmatic interpretation. Researchers have the freedom to build basic thinking from pragmatism, so that a grounded theory approach - a conditional matrix was used to analyze the research data (see, Trihatmoko \& Mulyani, 2018; Trihatmoko et al., 2018). The results of data processing and analysis were interpreted or described textually and structurally (Creswell, 2013; Taylor et al., 2016). In this context, new findings are formulated descriptively in the form of propositions and described as constructs as a form of conception of the results of this study (Cresswell, 2013). Furthermore, the results of this research were theoretically discussed in the previous literatures that were relevant to the research findings in which the implications for marketing and business practices were known.

\section{Results}

\subsection{Promotion Strategy and Product Performance}

Promotional activities of a product are intended by marketers to achieve a product performance. The supplier's promotion strategy policy provides the possibility of the buyer's response to "buy or reject" the product offer by the supplier. Likewise, buyers assess "whether" programs or product promotion activities have an impact on the success of products in competing with products that already exist in stores and in the consumer market. This finding identifies that first of all the promotion strategy policies by companies fall into the business market competition. The phenomenon of promotional strategies by suppliers explains that promotions enter the realm of customer market competition "wholesalers: buy or reject", and the consumer market. This phenomenon illustrates that the program or product promotion activities by companies - companies have the potential to change the situation of business competition and consumers, as well as product prices. In the end, the good or bad performance of a product is very dependent on the competitive situation affected by the promotion program carried out by the product owners. This description is a confirmation that the performance of a product from the results and activities of a promotional strategy has the same rating, both from the point of view of the supplier and by the buyer. Thus, the arrangement or structuring of the promotion strategy description is theoretically in the form of a performance proposition of the following product (grounded theory - 1), and conceptualized as in Figure 1.

P1: Marketing environment - P: promotion of companies in initiating product promotion strategies has an impact on business market competition.

P2: Marketing environment - P: promotion of companies in carrying out promotional strategy initiatives has an impact on the competitive environment of the consumer market.

P3: Marketing environment - P: promotion of companies in initiating promotional strategies has an impact on the marketing environment - P: price about product pricing strategy initiatives.

P4: Marketing environment - P: the price of price strategy initiatives impacts on the competitive environment of the consumer market.

P5: The environment of business market competition affects the competitive environment of the consumer market.

P6: The environment of consumers' market competition influences the environment of business market competition.

P7: Business market competition environment and consumers determine the performance of a product. 


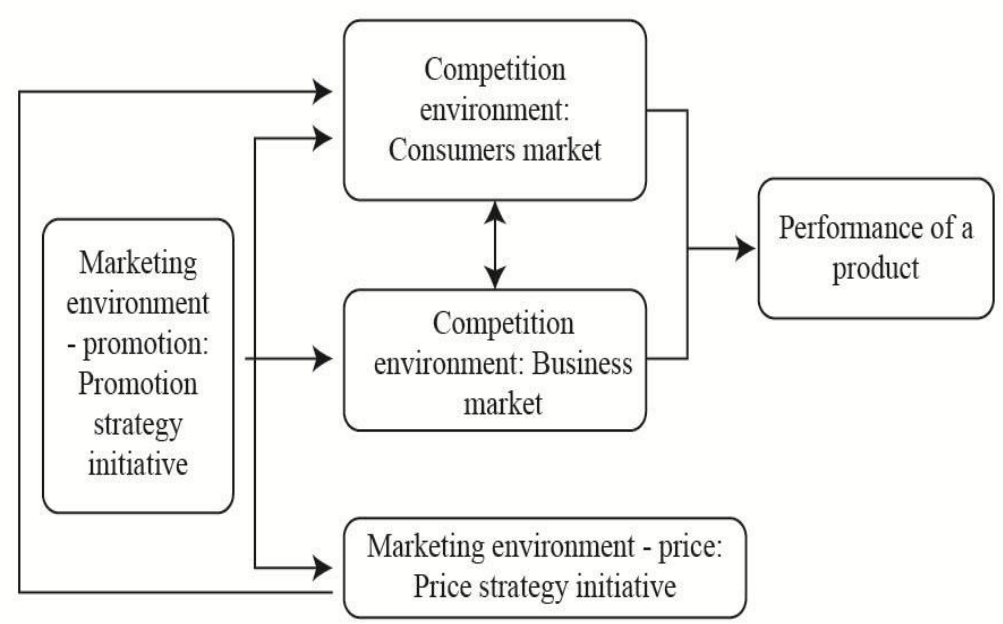

Figure 1. Performance of a product based on promotional strategies in market competition

Analysis of the content of Figure 1 directs to take a range of variables in Figure 1 to identify the performance parameters of a product in market competition. Inter-variable relationships are identified as indicators of measuring a product's performance, based on the intensity of the product promotion strategy.

Based on advertising and promotion analysis, as well as the above description of the promotional strategy theme, therefore, the grounded theory produces performance parameters for a product (Figure 1). The conception of product performance parameters needs to add a theorization of the brand image and image, which is different from the business buyer behavior concept. By analogy that image and brand reliability - products can have an impact on the creation of product demand by consumers, then, the minor propositions are:

P: Brand image and reliability - products drive the level of product demand.

\subsection{Configuration of Promotional Strategies in Supply Chain Management}

The success of a product from the determination of promotional strategies is to detect variables in Figure 2. The assessment uses pragmatic interpretation, and is arranged in a matrix form. There are two characteristics of product performance parameters, namely quantitative (measured mathematically) and qualitative (measured by perception). Promotional programs and their measurable impacts or outcomes are chosen as "conditional" matrix analysis tools. Advertising programs, sales promotions and consumer promotions require expenditure, thus the promotion expenditure becomes the first parameter. Second, the round of sales is the result of the company's sacrifice in financing marketing activities "promotional strategies". So, relative quantities of promotion expenditure and product sales rounds are identified as reflections to evaluate the success of a product in a certain period of time (Figure 3 ). 


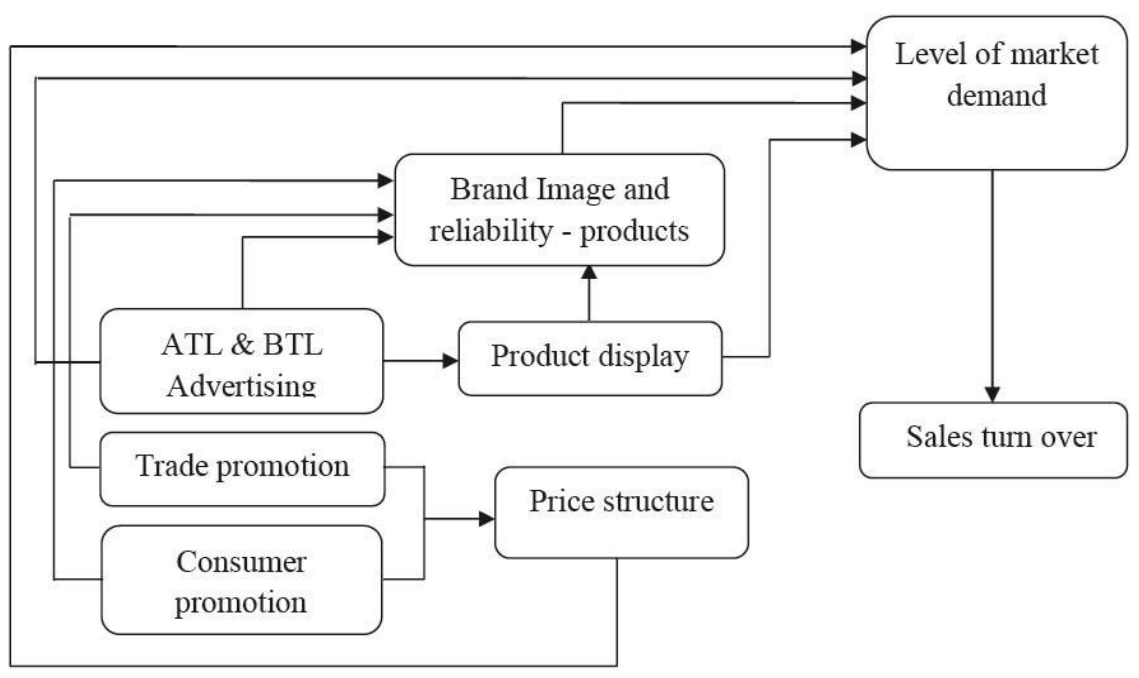

Figure 2. Parameters of the performance of a product are based on promotional strategies in market competition

The success or failure of product is described as following. High round sales performance with relatively low promotional costs making the product tend to be considered successful. This happens, for example when a new product uses a brand that is attached to a previously established product, so the advertising and promotion program is not too aggressive or costs are low. Conversely, a product tends to fail, namely a product that supports advertising and promotion costs is relatively small, and is not followed by a round of sales movements. Such a situation occurs, for example, the new product itself uses a new brand and does not have many product items in one family. Such products are generally due to the size of the company's product owners being relatively small-medium, while the competitors of the product belong to giant companies.

The product is likely to succeed or fail: Products that absorb advertising costs and promotions are high and are followed by a high sales progress round, and then it is likely to succeed in competing in the market. This happens because of the effectiveness of an intensive promotion program for a product at a certain period during the product launch period. Cost efficiency occurs when the brand's image and reliability are considered strong / good by the market, so the cost of advertising can be lowered or simply focus on sales promotion or consumer. In the condition that the cost of advertising and promotion is very large, but does not increase the volume of sales, it is likely that the product will fail to compete in the market. The possibility of product failure in such situations is caused by inaccuracies in product strategy, price, and distribution (Figure 3: conditional matrix). 


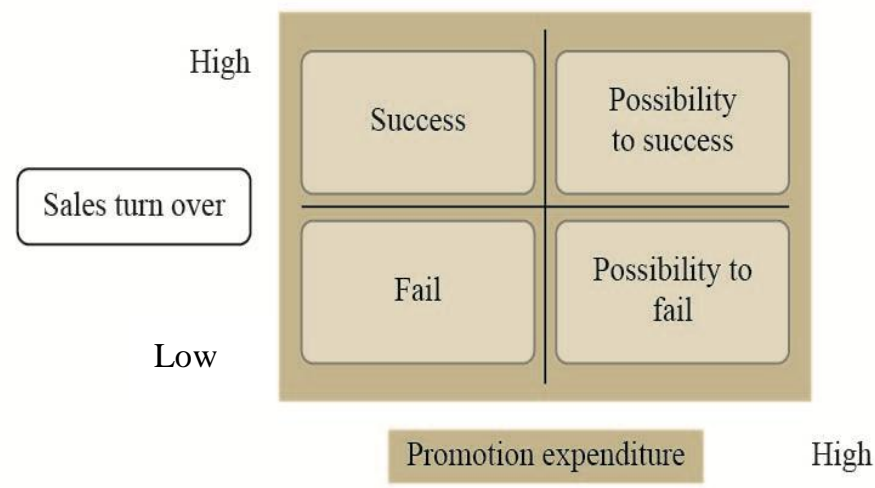

Figure 3. Evaluation of the success of products based on promotional strategies in the market competition

\section{Conclusion}

The research findings and discussion discussed previously provide conclusions and recommendations in response to the first problem of this paper. Buyers responding to new product offerings directly consider marketing environmental factors - P: promotion about advertising promotion programs, as well as trade \& consumer promotions. Reasons for buyers to: (1) find out that sales promotions have an impact on the marketing environment P: price about price structures and profit opportunities for buyers, and consumer promotions provide an attraction for consumers to market these products; (2) assessing the promotion of advertising "ATL and BTL" to compete in its area in product display activities and brand image development and reliability; and (3) expect their knowledge and assessment of the marketing environment and product competition to have the opportunity to create product sales demand and rotation in the competitive environment in general. The buyers' argument in the general trading business perspective is that they want to benefit from the product sales prospects and the value-added benefits of the program and promotional activities that are carried out and offered by their suppliers.

Hence, it is recommended to top management in compiling a corporate strategy, namely: (1) initiating a new product promotion strategy must be in accordance with the balance between the sales budget and the total marketing costs of the business; (2) in each brand strategy choice plan (line extensions, brand extensions, multi brands, or new brands) it is necessary to calculate the promotion cost budget for the period of product development in the market (advice, at least 2 years). Analysis of the average amount of promotional budget realization with the achievement of sales rounds becomes a strategic tool in product marketing for the next time. The techniques and types of promotional strategy initiatives need to be chosen in the future "where and what they are like" identified and assessed the effectiveness and efficiency of the success of the product itself. For this reason, the next recommendation is an assessment of organizational performance in the promotion department, referring to the evaluation of the achievement of the sales cycle with the realization of promotional costs, on each unit and categorical product. This assessment is deemed appropriate because it is open, measurable and objective, so it does not cause misunderstandings between organizational lines in the context of the overall corporate strategy.

\section{Limitations and Future Research Agenda}

The advantage of this paper is to present the depth of intensity of new product promotion strategies in the FMCG market competition in the business and consumer environment according to the target and market segmentation. However, the marketing strategy depth is not only limited to promotional strategies, but also on pricing and placement strategies, and product innovation strategies themselves. In this context, the results of research or new research projects on price, place and product can provide new colors in the knowledge of marketing mix and buying behavior in the business market or consumer market. As a concern, understanding both marketing mix and buying 
behavior, both of which are interrelated in the realm of marketing strategies, especially for mass products that use the channel management approach.

The intensity of the promotion strategy in this research is the object of marketing new products. Market phenomena indicate that the intensity of promotional activities is not only for new products, but also for products that are already established in the market. This points out that the market leader in contemporary market, will be threatened by product newcomer as it challengers. Reflections on the illustration of the statement suggest that the position of the product in market competition is not enduring or the dynamics of its journey are difficult to predict. So, future research opportunities can use the conceptual framework of the results of this research as hypotheses in quantitative research, or as a guide in qualitative research to research products that have been established in the market. New results for future research are expected to contribute in generalizing foundation or conceptions in this paper.

The limitations of this study rely on the consideration that the salesperson's role as part of the promotion mix has not been touched by the deepening of this paper. The salesperson phenomenon itself has a variety of different functions and types of assignments according to the strategic policies set by the company. For this reason, research on the role and function of salespersons in the context of promotion mix is still open to researchers in the future.

\section{References}

Achrol, R. S., Reve, T., \& Stern, L. W. (1983). The environment of marketing channel dyads: a framework for comparative analysis. Journal of Marketing, 47(4), 55-67.

Aman, A., \& Hopkinson, G. (2010). The changing structure of distribution channels in Pakistan. International Journal of Retail \& Distribution Management, 38(5), 341-359.

Baggen, B. E. A., Wouters, J. P. M., \& Nijssen, E. J. (2010). The relationship between advertising and likelihood to recommend: An investigation within the Net Promoter Score context at Philips. Technische Universiteit Eindhoven.

Breiter, A., \& Huchzermeier, A. (2015). Promotion planning and supply chain contracting in a high-low pricing environment. Production and Operations Management, 24(2), 219-236.

Buil, I., De Chernatony, L., \& Martínez, E. (2013). Examining the role of advertising and sales promotions in brand equity creation. Journal of Business Research, 66(1), 115-122.

Chaudhuri, M., Calantone, R. J., Voorhees, C. M., \& Cockrell, S. (2018). Disentangling the effects of promotion mix on new product sales: An examination of disaggregated drivers and the moderating effect of product class. Journal of Business Research, 90, 286-294.

Chen, S. F. S., Monroe, K. B., \& Lou, Y. C. (1998). The effects of framing price promotion messages on consumers' perceptions and purchase intentions. Journal of Retailing, 74(3), 353-372.

Creswell, J. (2009). Research Design: Quantitative, Qualitaitive and Mixed method approach. SAGE Publication.

Creswell, J. W., \& Poth, C. N. (2017). Qualitative inquiry and research design: Choosing among five approaches. SAGE Publication.

Evans, J. R., \& Berman, B. (1992). Marketing. New York, USA: Macmillan Publishing Company.

Fatchan, H. A. (2011). Metode Penelitian Kualitatif. Surabaya: Jenggala Pustaka Utama.

Hackley, C., \& Hackley, A. R. (2019). Advertising at the threshold: Paratextual promotion in the era of media convergence. Marketing Theory, 19(2), 195-215.

Jackson, D. W., Keith, J. E., \& Burdick, R. K. (1984). Purchasing Agents' Perceptions of Industrial Buying Center Influence: A Situational Approach. Journal of Marketing, 48(4), 75-83.

Jallow, H., \& Dastane, O. (2016). Effect of Sales Promotion Schemes on Purchase Quantity: A Study of Malaysian Consumers. Management \& Marketing, 14(2).

Jin, Y., Wang, S., \& Hu, Q. (2015). Contract type and decision right of sales promotion in supply chain management with a capital constrained retailer. European Journal of Operational Research, 240(2), 415-424.

Jonker, J., \& Penning, B. (2010). The Essence of Research Methodology. Berlin, Germany: Springer.

Kotler, P., \& Armstrong, G. (2013). Principles of Marketing. Harlow, England: Pearson Education Limited.

Martínez, E., \& de Chernatony, L. (2004). The Effect of Brand Extension Strategies upon Brand Image. Journal of Consumer Marketing, 21(1), 39-50. 
Nijssen, E. J., \& Agustin, C. (2005). Brand Extension: A Manager's Perspective. Journal of Brand Management, 13(1), 33-49.

Nijssen, E. J. (1999). Success Factors of Line Extensions of Fast Moving Consumer Goods. Journal of Marketing, 33(5/6), 450-474.

Orth, U. R., McDaniel, M. T., Shellhammer, \& Lopetcharat, K. (2004). Promoting Brand Benefits: The Role of Consumer Psychographics and Lifestyle. Journal of Consumer Marketing, 21(2/3), 97-108.

Peter, J. P., \& Donnelly, Jr. J. H. (2011). Marketing Management. New York: McGraw-Hill Companies, Inc

Power, D. J., Sohal, A. S., \& Rahman, S. U. (2001). Critical success factors in agile supply chain management-An empirical study. International Journal of Physical Distribution \& Logistics Management, 31(4), 247-265.

Proctor, T. (2005). Essentials Marketing Research. Harlow, England: Pearson Education Limited

Rampier, M. (2012). Sales Promotion of Fast Moving Consumer Goods. International Journal of Logistics \& Supply Chain Management Perspectives, 1(1), 59.

Robinson, P., Wind, Y., \& Faris, C. W. (1967). Summary Information: Industrial Buying and Creative Marketing. Allyn \& Bacon.

Sashi, C. M. (2009). Buyer Behavior in Business Markets; A Review and Integrative Model. The Journal of Global Business Issues, 3(2), 129-138.

Siddiqi, Z., Nasim, S., Saleem, F., \& Ali, S. G. (2015). Analysis of BTL Activities on Customer Satisfaction of Tea. Asian Journal of Research in Marketing, 4(2), 26-34.

Solomon, M. R. (2013). Consumer Behavior. Harlow, England: Pearson Education Limited.

Stern, L. W., \& Reve, T. (1980). Distribution Channels as Political Economies: A Framework for Comperative Analysis. Journal of Marketing, 44(3), 52-64.

Tang, Y-C., Wang, Y-M., \& Huang, J-Y. (2014). Optimal Promotional Strategy for Intra-category Cross-selling An Application to Culinary Products in Taiwan. British Food Journal, 116(1), 80-90.

Taylor, S. J., Bogdan, R., \& DeVault, M. L. (2016). Introduction to Qualitative Research Methods. John Wiley \& Son, Inc.

Trihatmoko, R. A., \& Mulyani, R. (2018). Distribution Strategy for New Product Marketing Success: Fast Moving Consumer Goods (FMCG) Business. Management and Human Resource Research Journal, 7(12), 19-32.

Trihatmoko, R. A. (2016). Proses Keputusan Pembelian Produk Baru oleh Grosir Industri Fast Moving Consumer Goods (FMCG) di Pasar Tradisional. Disertasi Pascasarjana Program Studi Doktor Ilmu Ekonomi. Universitas Sebelas Maret, Surakarta, Indonesia. Retrieved from https://digilib.uns.ac.id/dokumen/detail/57395/Proses-Keputusan-Pembelian-Produk-Baru-oleh-Grosir-IndustriFast-Moving-Consumer-Goods-FMCG-di-Pasar-Tradisional

Trihatmoko, R. A., Harsono, M., Wahyuni, S., \& Haryono, T. (2016a). Buyer-Seller Relationship Construction in The Business Buyer Behavior: Wholesaler and Distributor Fast Moving Consumer Goods (FMCG) Industry in Indonesian Market Place. International Journal of Research in Commerce \& Management, 7(5), 24-33.

Trihatmoko, R. A., Harsono, M., Wahyuni, S., \& Haryono, T. (2016b). The Confine of Efficient Contract Between Principals and Distributors Perfectly Control of Marketing Mix Strategies: Channel Management Perspective of Fast Moving Consumer Goods (FMCG) Industries in Indonesian. International Journal of Research in Commerce, Economics \& Management, 6(9), 31-36.

Trihatmoko, R. A., Harsono, M., Wahyuni, S., Haryono, T., \& Lukviarman, N. (2018). Structure of Channel Management and Agency Theory: Relationship Marketing Approach for Fast Moving Consumer Goods (FMCG) Business. Research in Business and Management, 8(2), 25-37.

Trihatmoko, R. A., Mulyani, R., \& Lukviarman, N. (2018). Product Placement Strategy in the Business Market Competition: Studies of Fast Moving Consumer Goods. Business and Management Horizon, 6(1), 150-161.

Trihatmoko, R. A., Napitupul, S., Purnamasari, D. I., \& Kurniwanto, H. (2018). An Assessment of the Demand for New Products of Fast Moving Consumer Goods (FMCG). Business Management and Strategy, 9(2), 18-39. 
Trihatmoko, R. A., \& Purnamasari, D. I. (2019). New Product Pricing Strategy and Product Performance Assessment in Fast Moving Consumer Goods. International Journal of Economics \& Business Administration, 7(4), 417-423.

Tsao, Y. C., \& Sheen, G. J. (2012). Effects of promotion cost sharing policy with the sales learning curve on supply chain coordination. Computers \& Operations Research, 39(8), 1872-1878.

Verbeke, W., Bagozzi, R. P., \& Farris, P. (2006). The Role of Key Account Program, Trust, and Brand Strength on Resource Allocation in Channel of Distribution. Journal of Marketing, 40(5/6), 502-532.

Wahyuni, S., \& Ginting, M. (2017). The impact of product quality, price and distribution on purchasing decision on the Astra motor products in Jakarta. Arthatama: Journal of Business Management and Accounting, 1(1), 18.

Xiao, T., Yu, G., Sheng, Z., \& Xia, Y. (2005). Coordination of a supply chain with one-manufacturer and two-retailers under demand promotion and disruption management decisions. Annals of Operations Research, 135(1), 87-109.

Ziliani, C., Ieva, M., Gázquez-Abad, J. C., \& D’Attoma, I. (2019). Retail promotional communication: The comparative effectiveness of print versus online. In Exploring Omnichannel Retailing (pp. 225-249). Springer, Cham. 